\title{
ASMENŲ, PRIKLAUSOMŲ NUO ALKOHOLIO, PSICHOEMOCINE SVEIKATA
}

\author{
Jonas Sąlyga ${ }^{1,2}$, Vitalija Paškevičienė ${ }^{2}$ Geriuldas Žiliukas ${ }^{1,2}$ \\ ${ }^{1}$ Klaipédos jūrininku ligonine, ${ }^{2}$ Klaipédos universiteto Sveikatos mokslu fakultetas
}

Raktažodžiai: priklausymas nuo alkoholio, psichoemocinè sveikata.

\section{Santrauka}

Priklausymas nuo alkoholio - sunki lètinè liga, kuri sutrikdo ne tik priklausomų asmenų socialinę aplin$\mathrm{ką}$, bet ir psichoemocinę sveikatą. Kiekvienais metais vis didèja ir besigydančiujų skaičius. Lietuvoje besigydančių nuo psichikos ir elgesio sutrikimu dèl alkoholio vartojimo $2013 \mathrm{~m}$. buvo 47,9 tūkst, o 2014 metais šis skaičius išaugo iki 49,8 tūkst. Šiame darbe buvo nagrinejjama priklausomų nuo alkoholio asmenų, lankančių ir nelankančių (besigydančių stacionare) anoniminių alkoholiku grupes, psichoemocinè sveikata.

Tyrimo tikslas - išanalizuoti asmenų, priklausomų nuo alkoholio, psichoemocinę sveikatą.

Tyrimo metodika. Atliktas kiekybinis tyrimas. Naudoti instrumentai: Hospitaline nerimo ir depresijos (HAD) skale ir A. Antonovsky sutrumpintas gyvenimo orientacijos klausimynas (SOC - 13), skirtas vidinès darnos lygiui ịvertinti. Imtị sudarè - 322 respondentai, iš kurių 170 lankantys anoniminių alkoholiku grupes ir 152 - besigydantys stacionare. Aprašomoji duomenų analizè atlikta statistiniu programu paketu „SPSS 17.0.1 for Windows". Tyrimas atliktas laikantis etikos principų.

Tyrimo rezultatai. Nustatyta, kad tarp tiriamųjų, lankančių anoniminių alkoholikų grupes, buvo žymiai daugiau asmenų, nejaučiančių nerimo, išsiskyrė reikšmingai daugiau asmenų be depresijos simptomų nei tarp nelankančių anoniminių alkoholikų grupių. Stipresnès vidinès darnos tiriamieji turèjo mažesnį nerimo ir depresijos išreikštumą nei silpnesnès vidinès darnos tiriamieji. Tyrimo metu nustatyta, kad tiriamujų, lankančių anoniminių alkoholiku grupes, nerimo ir depresijos išreikštumą didino jaunesnis amžius, trumpesnis alkoholio vartojimo laikotarpis, problemų dèl alkoholio vartojimo turèji- mas, žemesnis išsilavinimas ir darbo neturejjimas. Tiriamujjų, nelankančių anoniminių alkoholikų grupių, nerimo išreikštumą didino vienišumas, dažnesnis alkoholio vartojimas ir problemų dèl alkoholio vartojimo turejjimas, o depresijos išreikštumą - vienišumas. Tyrimo rezultatai parodè, kad aukštesnius vidinès darnos, būtent, prasmingumo ir kontrolès vertinimus turèjo tiriamieji, kurie rečiau vartodavo alkoholi ir asmenys su aukštesniu išsilavinimu. Abiejose tiriamujų grupese priklausomai nuo anoniminių alkoholikų grupių lankymo vidinè darna nelankantiems buvo susijusi su šeimine padètimi, o lankantiems - su amžiumi.

Išvada. Nustatyta, kad asmenų, priklausomų nuo alkoholio, lankančių anoniminių alkoholikų grupes, psichoemocinè sveikata yra geresnè už nelankančių.

\section{İvadas}

Priklausomybès ligos kaip sudètinè fizinès, psichikos sveikatos ir socialine problema nepraranda aktualumo ịvairiuose socialiniuose sluoksniuose bei kultūrinèse aplinkose [1]. Nuo seniausių laikų iki XXI a. alkoholis palietė kultūrinę, religinę, socialinę, politinę ir ekonominę visuomenès gyvenimo sferas. Alkoholiui suteikiama simbolinè reikšmè, jis susietas su ritualais, simbolizuoja svetingumą, vartojat mas vestuvių, gimimo, laidotuvių ceremonijose [2]. Dažnai vartojant alkoholi išsivysto sunki ir viską griaunanti liga - alkoholizmas ir su juo susijusios problemos. Lietuvoje alkoholio suvartojimas itin didelis. Pasaulinès sveikatos organizacijos duomenimis, Lietuva pagal legalaus (mažmeninejje prekyboje ir maitinimo įmonèse parduotų alkoholinių gèrimų kiekis litrais, perskaičiuotas ị absoliutų alkoholị (100 proc.), tenkantis vienam gyventojui) ir nelegalaus suvartojamo alkoholio kieki pasaulyje yra trečioje vietoje (15,4 litru grynojo alkoholio asmeniui nuo 15 metų ir vyresniems). Lietuvą aplenkia tik Baltarusijos (17,5 litrų ) ir Moldovos Respublikos (16,8 litru). Policijos departamento prie Lietuvos Respublikos vidaus reikalų ministerijos duomenimis, 2014 m. užregistruoti 509 kelių eismo įvykiai dèl 
neblaivių asmenų kaltès, t. y. kas šeštą užregistruotą ịvykị sukèlè neblaivus asmuo. Juose žuvo 104, buvo sužeistas 891 žmogus. Dẻl kas antro neblaivių asmenų sukelto kelių eismo įvykio buvo kalti neblaivūs vairuotojai. Dèl jų kaltès pernai žuvo 45 ir buvo sužeisti 408 žmonès. Valstybinio psichikos sveikatos centro duomenimis, 2014 m. 531 asmuo pirmą kartą kreipèsi ị sveikatos priežiūros įstaigas dèl alkoholinès psichozès (184 asmenimis mažiau nei $2013 \mathrm{~m}$.) ir 1,4 tūkst. asmenų - dèl lètinio alkoholizmo (60 asmenų daugiau nei 2013 m.). 2014 m. pabaigoje dèl alkoholinès psichozès gydymo îstaigose gydèsi 3,2 tūkst. (2013 m. 3,4 tūkst.) asmenų ir dèl lètinio alkoholizmo - 46,6 tūkst. (2013 m. - 47,9 tūkst.) asmenų. Higienos instituto Sveikatos informacijos centro duomenimis, praejusiais metais dèl alkoholio vartojimo mire 758 žmonès. Dažniausios alkoholio vartojimo sukeltos mirties priežastys buvo alkoholinė kepenų liga (44,7 proc.), atsitiktinis apsinuodijimas alkoholiu (31,9 proc.) ir alkoholinė kardiomiopatija (12,9 proc.). $2014 \mathrm{~m}$. vyrų mirtingumas dèl alkoholio vartojimo buvo beveik 4 kartus didesnis negu moterų [3]. Atlikta nemažai tyrimų priklausymo nuo alkoholio tematika, Alber et al. 2004; Guide 2005, Schuessler, Fisher 1985; Meacher 2001; Fahey et al. $2003 \mathrm{~m}$. tyrè priklausomų nuo alkoholio asmenu gyvenimo kokybę, J. Kaliatkaitè, L. Bulotaite, B. Pajarkienė $2010 \mathrm{~m}$. analizavo vyrų, priklausomų nuo alkoholio, žmonų psichologinès savijautos rodiklių sąsajas su savipagalbos grupių lankymu, Kelly et al. 2009 m. tyré priklausomų nuo alkoholio asmenų elgesio pasikeitimus, depresijos mažejimą lankant savitarpio pagalbos grupes. Lietuvoje atliktų tyrimų apie anoniminių alkoholikų grupių įtaką psichoemocinei savijautai yra ganètinai mažai. Vidinė tokių asmenų darna taip pat mažai nagrinèta. Pažymètina, kad nèra nuodugniai ištirta, kaip kinta asmenų, priklausomų nuo alkoholio, psichoemocinè būsena lankant savipagalbos grupes. Kadangi ši sritis mažai analizuota, tačiau yra pakankamai aktuali, būtina plačiau išnagrinèti bei ištirti anoniminių alkoholikų grupių įtaką asmenų psichoemocinei sveikatai.

Tyrimo tikslas - išanalizuoti asmenų, priklausomų nuo alkoholio, psichoemocinę sveikatą.

\section{Tyrimo medžiaga ir metodai}

Tyrimas buvo atliktas vienoje Vakaru Lietuvos gydymo ịstaigų, teikiančiu stacionarines paslaugas asmenims, priklausomiems nuo alkoholio ir keliose Vakarų Lietuvoje veikiančiose anoniminių alkoholikų grupèse nuo $2015 \mathrm{~m}$.

Itraukimo i tyrimą kriterijai: asmenys nuo $18 \mathrm{~m}$. amžiaus; asmenys, turintys ar turejję problemų dèl alkoholio vartojimo; asmenys, lankantys anoniminių alkoholikų grupes; asmenys, besigydantys tik stacionare ir nelankantys anoniminių alkoholikų grupių; asmenys, sutikę savanoriškai dalyvauti tyrime; asmenys, suprantantys lietuvių kalbą. Neįtraukimo ị tyrimą kriterijai: asmenys, nesutikę dalyvauti tyrime; asmenys, nesuprantantys lietuvių kalbos; asmenys, bent kartą pildę klausimyną; sugadintos anketos. Tiriamaji kontingentą sudare 322 asmenys, priklausomi nuo alkoholio, iš kurių 170 (52,8 proc.) lankè anoniminių alkoholikų grupes ir 152 (47,2 proc.), kurie grupių nelankè, bet gydèsi stacionare. Tyrime dalyvavo asmenys nuo 20 iki 80 metų (amžiaus vidurkis 47,32 $\pm 11,77$ metų, medianą - 48 metai, suskirsčius pagal medianą $156(48,4$ proc.) tiriamieji buvo iki 48 metų ir 163(50,6 proc.) - 48 metų ir vyresni). Dauguma (71,1 proc.) iš jų buvo vyrai, o moterų - 28,9 proc. Tiriamieji, lankantys anoniminių alkoholiku grupes (1 grupè), buvo vyresni nei nelankantys (2 grupè) (atitinka-

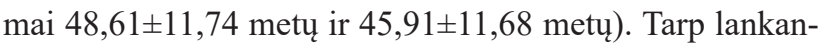
čių šias grupes buvo žymiai daugiau moterų (atitinkamai 39,4 proc. ir 17,1 proc.), dirbančiu (atitinkamai 63,5 proc. ir 41,4 proc.), nevienišų, t.y. turinčių partnerị (atitinkamai 55,3 proc. ir 38,8 proc.) nei nelankančių grupejje (1 pav.).

Psichoemocinẻ būklè vertinta naudojant Hospitalinę nerimo ir depresijos skalę (HAD). Lietuvoje skalę adaptavo 1991 m. R. Bunevičius ir S. Žilènienè. 2014 m. spalio mèn. gautas leidimas iš J. Burkausko skalę naudoti tyrime.

Vidinès darnos lygiui nustatyti naudotas Antonovsky (1987) sutrumpintas gyvenimo oreintacijos anketinis klausimynas (SOC - 13). Leidimas naudoti gautas iš Z. Javtoko $2015 \mathrm{~m}$. balandžio mèn. Vidinei darnai matuoti buvo naudojamos šios poskalès: aiškumas, prasmingumas, kontrolè.

Atlikus tyrimą, jo rezultatų analizei buvo naudojamas statistinis programų paketas ,SPSS 17.0.1 for Windows “. Tikrintas kintamujų pasiskirstymas pagal normaluji dèsnị naudojant Kolmogorov'o-Smirnov'o testą. Dviejų nepriklausomų grupių požymių palyginimui naudotas Stjudent'o kriterijus (t), kai požymiai buvo pasiskirstę pagal normaluji dèsni, o esant nenormaliam skirstiniui - neparametrinis Man'o-Vitni‘o (U) kriterijus. Daugiau nei dviejų nepriklausomų grupių požymių, pasiskirsčiusių pagal normalujj dèsni, palyginimui naudotas ANOVA (F) metodas, o nesant normaliam - Kruskal'o Wallis'o (2) kriterijus. Požymių pasitaikymo dažnumo skirtumams vertinti naudotas chi-kvadrato (2) kriterijus. Analizuojant koreliacinius imties požymių ryšius, priklausomai nuo požymių tipo ir pasiskirstymo, naudoti Pearson'o ar Spearmen'o koreliacijos koeficientai (r). İvairių požymių reikšmè nerimo ir depresijos išreikštumui buvo ịvertinta daugiamatès tiesinès regresijos pagalba.

Tyrimas atliktas laikantis etikos principų. 


\section{Tyrimo rezultatai}

Vidinès darnos ir psichoemocinès būklès tarpusavio sąsajos. Tyrimo rezultatai parode, kad tarp tiriamujų, lankančių anoniminių alkoholikų grupes, HAD skalès nerimo

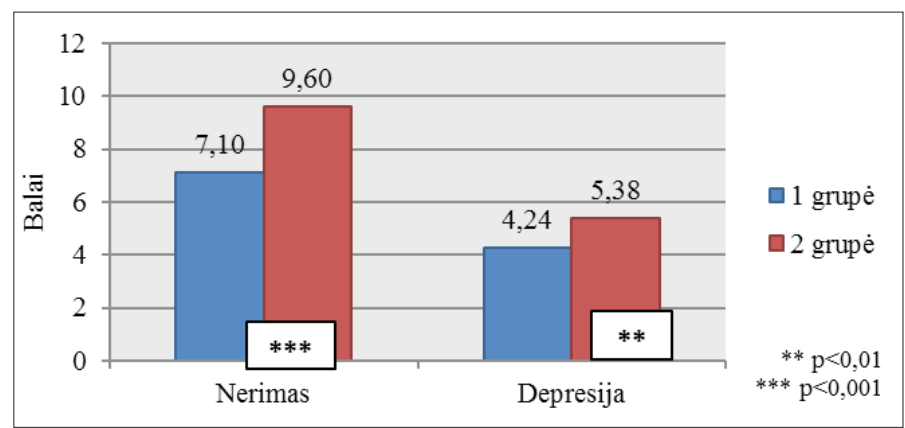

1 pav. Nerimo ir depresijos vertinimų skirtumai priklausomai nuo anoniminių alkoholikų grupių lankymo

Nerimui taikytas Stjudent'o kriterijus (t), depresijai-Man'o - Vitni'o (U) kriterijus

1 grupe - lankantys anoniminiu alkoholiku grupes; 2 grupe - nelankantys anoniminiu alkoholiku grupiu

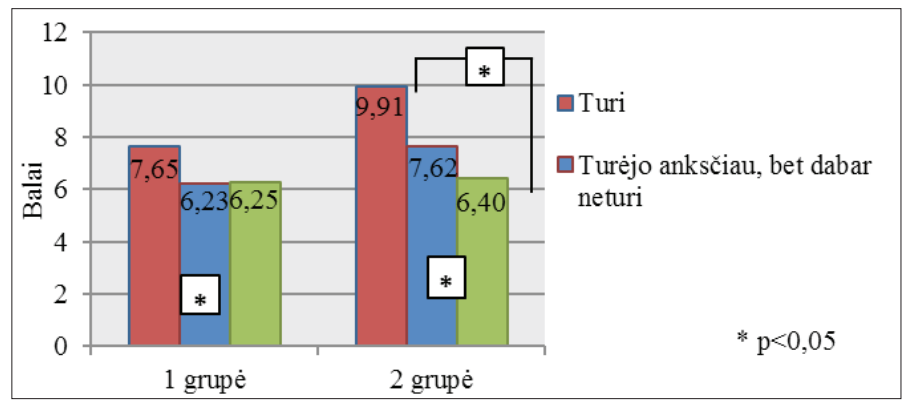

2 pav. Tiriamųjų, lankančių ir nelankančių anoniminių alkoholikų grupes, nerimo vertinimų skirtumai priklausomai nuo problemų dèl alkoholio vartojimo turejjimo

Taikytas ANOVA (F) metodas

1 grupé - lankantys anoniminiu alkoholiku grupes; 2 grupé - nelankantys anoniminiu alkoholiku grupiu.

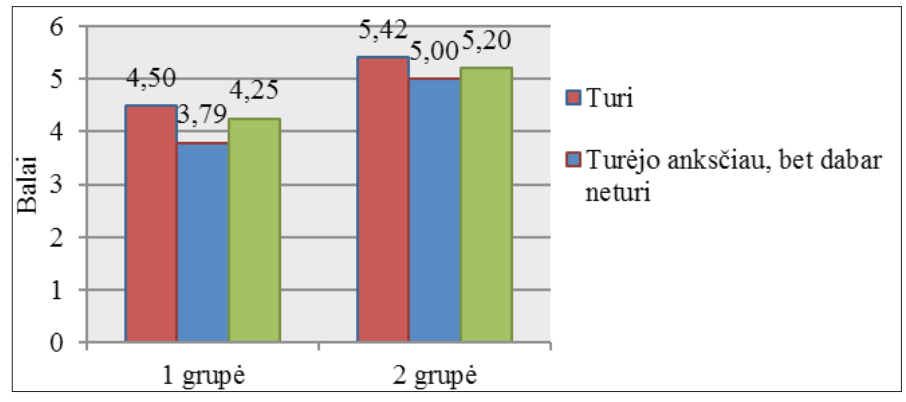

3 pav. Tiriamųjų, lankančių ir nelankančių anoniminių alkoholikų grupes, depresijos vertinimų skirtumai priklausomai nuo problemų dẻl alkoholio vartojimo turèjimo

Taikytas Kruskal'o Wallis 'o (c $\left.c^{2}\right)$ kriterijus

1 grupe - lankantys anoniminiu alkoholiku grupes; 2 grupé - nelankantys anoniminiu alkoholiku grupiu
(1 grupejje 7,10 $\pm 4,00$ balų, 2 grupejje $9,60 \pm 4,06$ balų: $t=5,55$ $\mathrm{p}<0,001)$ ir depresijos (1 grupeje $4,24(4,0)$ balų, 2 grupèje 5,38(5) balų: $U=10252,5 \mathrm{p}=0,001)$ ịverčiai buvo žymiai mažesni nei tarp nelankančiu anoniminių alkoholikų grupių. A. Antonovsky (1987) pasiūlè žiūrèti i sveikatą kaip ị tęstini procesą nuo gerovès iki ligos. Žmonès priklausomai nuo jų išprusimo, gebejjimo valdyti stresą, juda gerovès arba ligos link. Pagal A. Antonovsky, vidiné darna yra siejama su geresniu atsparumu stresui ir sveikata. Vidine darna labiausiai siejama su psichine sveikata - nerimu, depresija [4]. Tai patvirtino ir mūsų atlikto tyrimo rezultatai. Bendroje tiriamujų grupeje nustatyti itin reikšmingi $(p<0,001)$ ryšiai tarp nerimo, depresijos ir bendros vidinès darnos ir jos komponenčių - aiškumo, prasmingumo ir kontrolès vertinimu - tiriamieji su stipresne vidine darna turejo mažesnį nerimo ir depresijos išreikštumą nei tiriamieji su silpnesne vidine darna (2 pav.).

Analizuojant atskirai tiriamujų, lankančių ir nelankančių anoniminių alkoholikų grupes, nerimo vertinimus priklausomai nuo problemų dèl alkoholio vartojimo turejimo nustatyta, kad grupeje nelankančių anoniminių alkoholikų grupių tiriamujjų, kurie nurodè, kad turèjo problemų dèl alkoholio vartojimo, turejo daugiau nerimo simptomų nei tiriamieji, kurie tokių problemų turejjo anksčiau, bet dabar nebeturi ir tie tiriamieji, kurie tokiu problemų neturejjo (turèjo $9,91 \pm 3,91$ balų, turejo, bet dabar nebeturi 7,62 $\pm 4,63$ balų, neturejjo $6,40 \pm 4,39$ balų: $F=3,63 p=0,029)$. Turinčiu problemų dèl alkoholio vartojimo ir lankančių anoniminių alkoholikų grupes nerimo išreikštumas buvo reikšmingai $(p<0,05)$ didesnis nei tų tiriamujų kurie nurodè, kad tokių problemų turejjo anksčiau, bet dabar nebeturi. Reikšmingo skirtumo tarp turinčių ir neturinčių problemų dèl alkoholio vartojimo nenustatyta (3 pav.).

Analizuojant atskirai tiriamujų, lankančių ir nelankančių anoniminių alkoholikų grupes, depresijos vertinimus priklausomai nuo problemų dèl alkoholio vartojimo turejjimo reikšmingų skirtumų nenustatyta, tik pastebèta tendencija abiejose grupèse, kad tiriamųjų, kurie turèjo anksčiau problemų dèl alkoholio vartojimo, bet dabar nebeturi, depresijos vertinimai buvo šiek tiek mažesni nei tų tiriamujų, kurie turèjo ir neturèjo problemų dèl alkoholio vartojimo.

Vidinė darna ir sociodemografinès charakteristikos. Tiriamujų vidinei darnai ịvertinti naudota trumpoji vidinès darnos anketos versija (SOC - 13), kurią sudare 13 klausimų/teiginių, turinčių penkių atsakymo variantų skalę: nuo skaičiaus 1 (labai dažnai, 


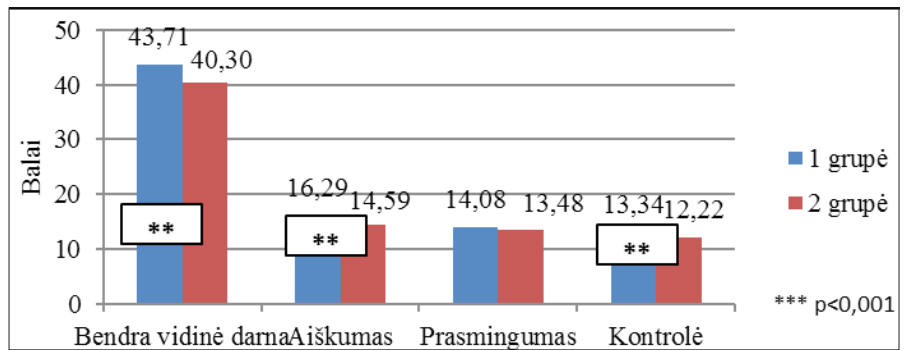

4 pav. Bendros vidinės darnos ir jos komponenčių vertinimų skirtumai priklausomai nuo anoniminių alkoholikų grupių lankymo

1 grupé - lankantys anoniminiu alkoholiku grupes; 2 grupé - nelankantys anoniminiu alkoholiku grupiu

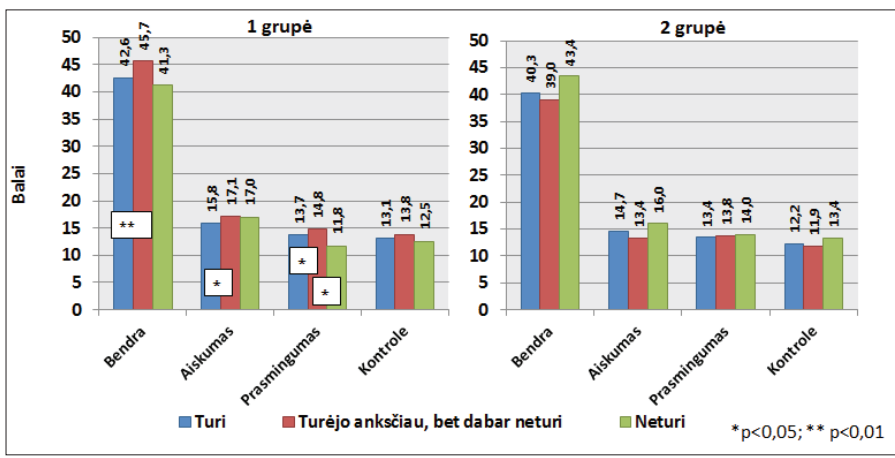

5 pav. Tiriamųjų, lankančių ir nelankančių anoniminių alkoholikų grupes, bendros vidinès darnos ir jos komponenčių vertinimų skirtumai priklausomai nuo problemų dèl alkoholio vartojimo turejjimo

Bendros darnos rodikliui taikytas ANOVA (F) metodas, kitiems - Kruskal'o Wallis 'o $\left(c^{2}\right)$ kriterijus patikslinant su Man'o-Vitni'o (U) kriterijumi

1 grupe - lankantys anoniminiu alkoholiku grupes; 2 grupe - nelankantys anoniminiu alkoholiku grupiu

blogiausia galima pozicija) iki 5 (niekada, geriausia galima pozicija). SOC - 13 versijoje sumuojami visu 13 klausimų atsakymai, kur bendra klausimyno atsakymu suma kinta ribose nuo 13 iki 65. Kuo ši suma yra didesnè, tuo vidinè darna yra aukštesnè. Taip pat vertintos ir atskiros vidinès darnos komponentès: aiškumas, prasmingumas ir kontrolè. Atsakymai buvo sumuojami kiekvienai komponentei atskirai ir pagal tai sprendžiama apie vieną ar kitą vidinès darnos dedamajį.

Bendroje tiriamuju grupeje bendrą vidinès darnos ịverčio vidurkị sudare 42,10 $\pm 7,43$ balų, aiškumo vidurkị - 15,49 $(15,0)$ balų, prasmingumo vidurkị - 13,80 $(14,0)$ balų ir kontrolès vidurki - 12,81(13,0) balų (4 pav.).

Bendram darnos rodikliui taikytas Stjudent'o kriterijus (t), kitiems rodikliams - Man'o - Vitni'o (U) kriterijus.

Tyrimo rezultatai parodè, kad tiriamujjų, lankančių anoniminių alkoholikų grupes, bendras vidinès darnos ( 1 grupejje $43,71 \pm 7,31$ balų, 2 grupeje $40,30 \pm 4,06$ balų: $t=4,22 p<0,001)$, aiškumo (1 grupejje 16,29(16,0) balų, 2 grupèje 14,59(15,0) balų: $U=9218,5 \mathrm{p}<0,001)$ ir kontrolès (1 grupeje 13,34(13,0) balų, 2 grupejje 12,22(12,0) balų: $U=9786,5 \mathrm{p}<0,001)$ vertinimai buvo žymiai aukštesni nei nelankančiujų anoniminių alkoholikų grupių. Prasmingumo vertinimai tarp grupių reikšmingai nesiskyrè.

Tyrimo rezultatai parode, kad bendroje tiriamujų grupejje bendros vidinès darnos vertinimui reikšmingos įtakos turèjo tiriamuju amžius $(r=0,18 \mathrm{p}=0,002)$, išsilavinimas $(\mathrm{r}=0,16 \mathrm{p}=0,003)$, darbinè padètis $(\mathrm{r}=-0,14$ $\mathrm{p}=0,013)$, problemų dèl alkoholio turèjimas $(\mathrm{r}=0,17$ $\mathrm{p}=0,003)$ ir ypač šeiminè padètis $(\mathrm{r}=0,30 \mathrm{p}<0,001)$; vidinès darnos komponentès aiškumo vertinimui amžius ( $\mathrm{r}=0,15 \mathrm{p}=0,008)$, problemų dèl alkoholio vartojimo turèjimas $(\mathrm{r}=0,18 \mathrm{p}=0,001)$ ir ypač šeiminè padètis $(\mathrm{r}=0,26 \mathrm{p}<0,001)$; vidinès darnos komponentès prasmingumo vertinimui - amžius $(r=0,12 \mathrm{p}=0,029)$, išsilavinimas $(\mathrm{r}=0,18 \mathrm{p}=0,001)$, darbinè padètis $(\mathrm{r}=-$ $0,16 \mathrm{p}=0,004)$, alkoholio vartojimo dažnis $(\mathrm{r}=0,15$ $\mathrm{p}=0,006)$, problemų dèl jo vartojimo turèjimas $(\mathrm{r}=0,12$ $\mathrm{p}=0,030)$ ir ypač šeimine padètis $(\mathrm{r}=0,25 \mathrm{p}<0,001)$; vidinès darnos komponentès kontrolès vertinimui - amžius $(r=0,16 \mathrm{p}=0,004)$, išsilavinimas $(\mathrm{r}=0,12 \mathrm{p}=0,035)$, problemų dèl alkoholio vartojimo turejjimas $(\mathrm{r}=0,13$ $\mathrm{p}=0,016)$ ir ypač šeiminè padètis $(\mathrm{r}=0,24 \mathrm{p}<0,001)(1$ lentelè).

Analizuojant bendros vidinès darnos ir jos komponenčių vertinimo sąsajas su tiriamujjų, lankančių anoniminių alkoholikų grupes, sociodemografiniais rodikliais bei alkoholio vartojimo dažniu ir trukme nustatyta, kad bendros vidinès darnos vertinimui reikšmingos ịtakos turèjo tiriamujų šeiminè padètis $(\mathrm{r}=0,24$ $\mathrm{p}=0,002)$, darbinè padétis $(\mathrm{r}=-0,15 \mathrm{p}=0,044)$, alkoholio vartojimo trukmè $(\mathrm{r}=0,17 \mathrm{p}=0,025)$ ir ypač amžius $(\mathrm{r}=0,29 \mathrm{p}<0,001)$; vidinès darnos komponentès aiškumo vertinimui - šeiminè padètis $(\mathrm{r}=0,20 \mathrm{p}=0,010)$, alkoholio vartojimo trukmè $(\mathrm{r}=0,19 \mathrm{p}=0,014)$ ir ypač amžius $(\mathrm{r}=0,25 \mathrm{p}=0,001)$; vidinès darnos komponentès prasmingumo vertinimui - išsilavinimas $(r=0,18$ $\mathrm{p}=0,019)$, darbinè padètis $(\mathrm{r}=-0,17 \mathrm{p}=0,029)$ ir šeiminè padètis $(\mathrm{r}=0,24 \mathrm{p}=0,002)$; vidinès darnos komponentès kontrolès vertinimui - tik amžius $(r=0,28$ $\mathrm{p}<0,001)$ (2 lentelè).

Amžiui ir bendros darnos rodikliui taikytas - Pearson'o koreliacijos metodas, visiems kitiems Spearmen'o koreliacijos metodas.

Analizuojant bendros vidinès darnos ir jos komponenčių vertinimo sąsajas su tiriamujų, nelankančių anoniminių alkoholikų grupių, sociodemografiniais rodikliais bei alkoholio vartojimo dažniu ir trukme nustatyta, kad bendros vidinès darnos vertinimui reikšmingos įtakos turèjo tiriamujų išsilavinimas $(r=0,16$ 
1 lentelè. Sociodemografinių rodiklių, alkoholio vartojimo dažnio ir trukmès sąsajos su bendra vidine darna ir jos komponentėmis tiriamųjų, lankančių anoniminių alkoholikų grupes

\begin{tabular}{|c|c|c|c|c|c|c|c|c|}
\hline \multirow{3}{*}{ Rodikliai } & \multicolumn{8}{|c|}{1 grupé } \\
\hline & \multicolumn{2}{|c|}{$\begin{array}{c}\text { Bendra } \\
\text { vidinė darna }\end{array}$} & \multicolumn{2}{|c|}{ Aiškumas } & \multicolumn{2}{|c|}{$\begin{array}{l}\text { Prasmin- } \\
\text { gumas }\end{array}$} & \multicolumn{2}{|c|}{ Kontrolè } \\
\hline & $\mathbf{r}$ & p & $\mathbf{r}$ & p & $\mathbf{r}$ & $\mathbf{p}$ & $\mathbf{r}$ & p \\
\hline Lytis $^{a}$ & $-0,05$ & 0,554 & $-0,11$ & 0,154 & 0,06 & 0,425 & $-0,07$ & 0,378 \\
\hline Amžius & 0,29 & $<0,001$ & 0,25 & 0,001 & 0,14 & 0,072 & 0,28 & $<0,001$ \\
\hline Išsilavinimas & 0,14 & 0,077 & 0,05 & 0,553 & 0,18 & 0,019 & 0,12 & 0,133 \\
\hline Gyvenamoji vietab & $-0,06$ & 0,424 & $-0,09$ & 0,240 & 0,08 & 0,307 & $-0,13$ & 0,099 \\
\hline Darbinè padètis $^{\mathrm{c}}$ & $-0,15$ & 0,044 & $-0,11$ & 0,162 & $-0,17$ & 0,029 & $-0,08$ & 0,317 \\
\hline Šeiminè padètis $^{\mathrm{d}}$ & 0,24 & 0,002 & $\mathbf{0 , 2 0}$ & $\mathbf{0 , 0 1 0}$ & 0,24 & 0,002 & 0,13 & 0,099 \\
\hline Alkoholio vartojimo dažnis & 0,07 & 0,367 & $-0,01$ & 0,950 & 0,15 & 0,057 & 0,05 & 0,557 \\
\hline Alkoholio vartojimo trukmè & $\mathbf{0 , 1 7}$ & 0,025 & $\mathbf{0 , 1 9}$ & 0,014 & 0,06 & 0,476 & 0,14 & 0,065 \\
\hline
\end{tabular}

2 lentelè. Sociodemografinių rodiklių, alkoholio vartojimo dažnio ir trukmės sąsajos su bendra vidine darna ir jos komponentemis tiriamųjų, nelankančių anoniminių alkoholikų grupių

\begin{tabular}{|c|c|c|c|c|c|c|c|c|}
\hline \multirow{3}{*}{ Rodikliai } & \multicolumn{8}{|c|}{2 grupè } \\
\hline & \multicolumn{2}{|c|}{$\begin{array}{c}\text { Bendra } \\
\text { vidiné darna }\end{array}$} & \multicolumn{2}{|c|}{ Aiškumas } & \multicolumn{2}{|c|}{$\begin{array}{c}\text { Prasmin- } \\
\text { gumas }\end{array}$} & \multicolumn{2}{|c|}{ Kontrolė } \\
\hline & $\mathbf{r}$ & $\mathbf{p}$ & $\mathbf{r}$ & p & $\mathbf{r}$ & $\mathbf{p}$ & $\mathbf{r}$ & p \\
\hline Lytis $^{a}$ & $-0,01$ & 0,864 & $-0,01$ & 0,893 & 0,04 & 0,587 & $-0,05$ & 0,508 \\
\hline Amžius & 0,01 & 0,963 & $-0,02$ & 0,829 & 0,08 & 0,301 & $-0,05$ & 0,579 \\
\hline Ǐsilavinimas & 0,16 & 0,048 & 0,12 & 0,132 & $\mathbf{0 , 1 7}$ & 0,042 & 0,07 & 0,375 \\
\hline Gyvenamoji vieta $^{\mathrm{b}}$ & $-0,08$ & 0,339 & $-0,04$ & 0,626 & $-0,09$ & 0,295 & $-0,07$ & 0,423 \\
\hline Darbinè padètis ${ }^{\mathrm{c}}$ & $-0,03$ & 0,744 & 0,04 & 0,666 & $-0,11$ & 0,162 & $-0,03$ & 0,714 \\
\hline Šeiminè padètis $^{\mathrm{d}}$ & 0,32 & $<0,001$ & 0,26 & 0,001 & 0,24 & 0,003 & 0,32 & $<0,001$ \\
\hline Alkoholio vartojimo dažnis & 0,19 & 0,018 & 0,15 & 0,058 & 0,25 & 0,002 & 0,12 & 0,140 \\
\hline Alkoholio vartojimo trukmè & 0,00 & 0,965 & $-0,02$ & 0,855 & $-0,03$ & 0,749 & $-0,01$ & 0,868 \\
\hline
\end{tabular}

\footnotetext{
$a$-požymis , Lytis “ turi dvi reikšmes: vyrai ,,1", moterys ,,2“;

b-požymis ,, Gyvenamoji vieta" turi dvi reikšmes: miestas ,, 1“, miestelis/kaimas ,,2 “,

c-požymis ,Darbinè padètis “ turi dvi reikšmes: dirbantys ,, 1“, nedirbantys ,,2 ";

$d$-požymis , Šeimine padètis “ turi dvi reikšmes: vieniši ,, 1 ", nevieniši , ,2 “;
}

$\mathrm{p}=0,048)$, alkoholio vartojimo dažnis $(\mathrm{r}=0,19 \mathrm{p}=0,018)$ ir ypač šeiminè padètis $(\mathrm{r}=0,32 \mathrm{p}<0,001)$; vidinès darnos komponentès aiškumo vertinimui - tik šeiminè padètis $(\mathrm{r}=0,26 \mathrm{p}=0,001)$; vidinès darnos komponentès prasmingumo vertinimui - išsilavinimas $(r=0,17 \mathrm{p}=0,042)$, šeiminè padètis $(\mathrm{r}=0,24 \mathrm{p}=0,003)$ ir alkoholio vartojimo dažnis $(\mathrm{r}=0,25 \mathrm{p}=0,002)$; vidinès darnos komponentès kontrolès vertinimui - tik šeiminè padètis $(r=0,32 \mathrm{p}<0,001)$.

Apibendrinus rezultatus, pateiktus 1 ir 2 lentelèse, darytina išvada, kad tiriamujjų, lankančių ir nelankančių anoniminių alkoholikų grupes, vidinè darna susijusi su šeimine padètimi, tačiau nelankantiems grupių šis faktorius yra stipriausias, kai tuo tarpu lankantiems grupes stipriausias faktorius yra amžius (5 pav.).

Analizuojant atskirai tiriamųjų, lankančių ir nelankančių anoniminių alkoholikų grupes, bendros vidinès darnos ir jos komponenčių - aiškumo, prasmingumo ir kontrolès vertinimus priklausomai nuo problemų dèl alkoholio vartojimo turëjimo nustatyta, kad tiriamujų grupejje, lankančių grupes, kurie nurodè, kad turejjo, bet dabar nebeturi problemų dèl alkoholio vartojimo, turèjo reikšmingai aukštesnius bendros vidinès darnos $(p=0,009)$ (turèjo $42,6 \pm 7,4$ balu, turejjo, bet dabar nebeturi $45,7 \pm 7,0$ balų, neturejjo $41,3 \pm 5,8$ balų: $F=3,71 p=0,027)$, aiškumo $(p=0,019)$ ( 1 grupeje: turèjo $15,8(16,0)$ balų, turèjo, bet dabar nebeturi $17,1(17,0)$ balų, neturèjo $17,0(16,5)$ balų: $\left.\mathrm{c}^{2}=5,64 \mathrm{p}=0,060\right)$ ir pras- 
mingumo $(\mathrm{p}=0,015)$ ( 1 grupèje: turèjo $13,7(14,0)$ balu, turejjo, bet dabar nebeturi 14,8(14,5) balų, neturèjo $11,8(11,0)$ balų: $\left.c^{2}=9,65 p=0,008\right)$ vertinimus nei tie tiriamieji, kurie turejo problemų dèl alkoholio vartojimo. Tiriamiesiems, kurie neturejo problemų dèl alkoholio vartojimo prasmingumo vertinimas buvo $(p=0,012)$ žemesnis nei tiriamujų, kurie turejjo problemų anksčiau bei dabar nebeturi. Tiriamiesiems, kurie nelankè anoniminių alkoholikų grupių, bendros vidinès darnos ir jos komponenčių - aiškumo, prasmingumo ir kontrolès vertinimai, priklausomai nuo problemų turejjimo dèl alkoholio vartojimo, reikšmingai nesiskyrè.

\section{Rezultatų aptarimas}

Analizuojant alkoholio vartojimo skirtumus, priklausomai nuo anoniminių alkoholikų grupių lankymo, tyrimo rezultatai parodè, kad tarp tiriamujų, lankančių anoniminių alkoholikų grupes, buvo žymiai daugiau asmenų, kurie vartojo ar vartodavo alkoholi kiekvieną dieną ar keletą kartų per savaitę nei grupejje, nelankančių anoniminių alkoholikų grupių. Apklausos metu problemų dèl alkoholio vartojimo turëjo 61,2 proc. tiriamujjų, lankančiu grupes ir 88,2 proc. - nelankančių. Tai rodo ir sutampa su R. Čižauskaitès [5] gautais tyrimo rezultatais. Lyginant lankančių ir nelankančių anoniminių alkoholikų grupių psichoemocinę sveikatą bendroje tiriamujų grupejje, nerimo skalès ịverčio vidurkị sudarė $8,28 \pm 4,21$ balų, depresijos $-4,77(4,0)$ balų. $\mathrm{H}$. M. Pettinati ir W. D. Dundon teigimu [6] tiek depresija, tiek priklausomybė nuo alkoholio didina riziką viena kitos atžvilgiu. Vienas sutrikimas yra susijęs su kito sutrikimo sunkumo lygiu. Be to, priklausomybè nuo alkoholio turi itakos depresijos eigai, o nuolatiniai depresijos simptomai yra rizikos veiksnys atkryčiams. A. Pranckevičienè [7] pažymi, jog tyrimai rodo aukštą depresijos komorbidiškumą su kitais psichikos sutrikimais.

Tarp tiriamujų, lankančių anoniminių alkoholikų grupes, buvo reikšmingai $(p<0,05)$ daugiau asmenų be depresijos simptomų nei tarp nelankančiųų anoniminių alkoholikų grupių. G. E. Vaillant [8] pažymi, jog anoniminiai alkoholikai atranda džiaugsmą padėdami kitiems, o dalyvavimas 12 žingsnių programoje prisideda prie ilgalaikio depresijos mažinimo. J. F. Kelly et al. [9] nurodo, kad dažnesnis anoniminių alkoholikų grupių lankymas susijęs su geresnèmis alkoholio vartojimo pasekmèmis ir depresijos mažejjimu. A. Kolbergytè ir V. Indrašienè [10] nurodo, kad žmonių dalyvavimas savitarpio pagalbos grupèse gerina jų emocinę būseną, jie išmoksta ,gyventi su savo problema“. M. Galanter [11] tyrimo rezultatai parode, kad lankant anoniminių alkoholikų grupes mažèja alkoholio potraukis, depresija, stiprejja dvasingumas, atsiranda daugiau teigia- mų emocijų. Todèl galima daryti prielaidą, kad anoniminių alkoholikų grupių lankymas mažina nerimo ir depresijos simptomus, o tai turi teigiamos ittakos psichoemocinei savijautai. Tai patvirtina ir R. Čižauskaitès [5] atliktas tyrimas, kad lankant anoniminiu alkoholiku grupes, pagerejo asmenų, turinčių problemų dèl alkoholio vartojimo, tiek fizinè, tiek psichinè sveikata, taip pat pagerèjo socialiniai santykiai ir aplinka.

A. Petrulytė ir kt. [12] nurodo, kad žemas vidinès darnos lygis labiausiai susijęs su psichologiniu diskomfortu. L. Pleskevičienès [13] teigimu, vidinè darna neigiamai koreliuoja su stresu bei sveikatos sutrikimo simptomais ir gali sumažinti streso ịtaką. Anoniminių alkoholikų grupių lankymas mažino nerimo išreikštumą $(\beta=-0,10, p=0,025)$. Kai vidinès darnos lygis yra žemas arba silpnas, kai tai, kas vyksta atrodo beveik nesuprantama, nesutvarkoma ir, be to, neturi prasmès, kyla tokie stiprūs nerimo ir streso jausmai, su kuriais sunku susidoroti [14]. Analizuojant nerimo išreikštumą, susijusį su kontrole, I. Preisaitė [15] nurodo, kad tiek vidinis, tiek išorinis sveikatos kontrolès lokusas prognozuoja nerimą. O G. Markevičius [16] pažymi, kad priklausomiems asmenims sunkiau kontroliuoti savo veiksmus, apėmus pykčiui, juos labiau kankina nepasitenkinimas savimi, o priklausomos asmenybès abejoja savo gyvenimo prasmingumu. L. Pleskevičienè [13] pabrèžia, kad žmogus, turintis silpną vidinę darną, jaučiasi sumišęs ir nepasitikintis. J. Dirsienè ir L. Zajančauskaitè - Staskevičienè [17] teigia, kad asmens ligos suvokimas nebūtinai dera su moksliniu požiūriu, tačiau būtent jis daro ịtaką pasirenkant ligos įveikos būdus.

Atlikus tyrimą apie asmenų, priklausomų nuo alkoholio psichoemocinę sveikatą, darytina išvada, kad asmenų, priklausomų nuo alkoholio, psichoemocinei būklei ịtakos turi jaučiamas nerimas, depresija, vidinè darna ir tiriamujjų sociodemografiniai rodikliai. Pažymètina, kad tyrimo anketos buvo išdalintos tik vienoje iš Vakarų Lietuvos gydymo istaigų, teikiančiu stacionarines paslaugas priklausomiems nuo alkoholio asmenims ir keliose Vakarų Lietuvoje veikiančiose anoniminių alkoholikų grupèse, todèl rezultatai neturètų būti vertinami kaip atspindintys asmenų, priklausomų nuo alkoholio psichoemocinę sveikatą visose Lietuvos anoniminių alkoholikų grupėse ir stacionaruose.

\section{Išvados}

1 Tyrimo rezultatai parodè, kad tiriamujų, lankančių anoniminių alkoholikų grupes, nerimo ir depresijos ịverčiai buvo žymiai mažesni, buvo žymiai daugiau asmenų, nejaučiančių nerimo, išsiskyrè reikšmingai daugiau asmenų be depresijos simptomų nei tarp nelankančių anoniminių alkoholikų grupių. Tiriamieji su stipresne vidine darna turèjo 
mažesnį nerimo ir depresijos išreikštumą nei tiriamieji su silpnesne vidine darna.

2. Tiriamujjų, lankančių anoniminių alkoholikų grupes, nerimo išreikštumą didino jaunesnis amžius, trumpesnis alkoholio vartojimo laikotarpis bei problemų dèl alkoholio vartojimo turejjimas. Depresijos išreikštumą - žemesnis išsilavinimas ir darbo neturejimas, kai tuo tarpu tiriamujų, nelankančių anoniminių alkoholikų grupių, nerimo išreikštumą didino vienišumas, dažnesnis alkoholio vartojimas ir problemų dèl alkoholio vartojimo turejimas, o depresijos išreikštumą - vienišumas.

3. Tyrimo rezultatai parodè, kad tiriamieji, gyvenantys su partneriu, vyresni asmenys, neturintys problemu dèl alkoholio vartojimo, turejjo aukštesnius bendros vidinès darnos ir jos visų sudedamųjų komponenčių (aiškumo, prasmingumo, kontrolès) vertinimus. Aukštesnius vidinès darnos, būtent, prasmingumo ir kontrolès vertinimus turejo tiriamieji, kurie rečiau vartodavo alkoholi ir asmenys su aukštesniu išsilavinimu. Abiejose tiriamųjų grupese, priklausomai nuo anoniminių alkoholikų grupių lankymo, vidinè darna buvo susijusi su šeimine padètimi - nelankantiems šis faktorius buvo stipriausias, o lankantiems - amžius.

4. Formuojant motyvaciją sveikti, tikslinga įtraukti ir šeimos narius, kadangi priklausomybè nuo alkoholio ne vien tik priklausomo asmens problema, bet ir visos šeimos. Todèl sveikimo procese labai svarbus artimujų palaikymas, pagalba. Reikètų informuoti priklausomus nuo alkoholio asmenis apie anoniminių alkoholikų grupių teikiamą naudą, jų pagalbos efektyvumą, kviesti anoniminių alkoholikų grupès narius, kurie pasidalintų savo patirtimi, baigus gydymą stacionare skatinti ir motyvuoti lankyti savipagalbos grupes blaivybei palaikyti.

\section{Literatūra}

1. Jasiukevičiūtė T., Danilevičiūtè V., Pajarskienẻ B. Būsimų medicininès, psichologinès ir socialinès pagalbos specialistu požiūris ị priklausomybę besigydančius asmenis. Visuomenès sveikata, 2010; 50 (3): 90 - 99.

2. Tamutienè I. Alkoholio vartojimo ir priklausomybès nuo alkoholio sąvokų apibrěžties problematika: socialinès dimensijos įtraukties aspektas. Socialinių tyrimų žurnalas, 2014; 5 (2): 179. http://dx.doi.org/10.7220/2335-8777.5.2.8

3. Narkotikų, tabako ir alkoholio kontrolès departamentas. Alkoholio vartojimas ir padariniai. 2014. http://www.ntakd.lt/index. $\mathrm{php} /$ statistika.

4. Vaitkevičius J. V. Sveikatos rizikos veiksnių valdymas ir savikontrolè ugdymo srityje. Mokomoji knyga. Šiauliai, 2005; 12.

5. Čižauskaitė R. Anoniminių alkoholikų grupių ịtaka alkoholị vartojančių asmenų gyvenimo kokybei. Vilnius. Magistro tezės,
2010; 5-56.

6. Pettinati HM, Dundon WD. Comorbid depression and alcohol dependence. Psychiatric Times 2011; 28 (6): 1-8 .

7. Pranckevičienė A. Depresija sergančių asmenų savijauta ir subjektyvus gyvenimo vertinimas stacionarinio gydymo laikotarpiu, Kaunas. Dakataro disertacija, 2008; 41.

8. Vaillant GE. Positive emotions and success of alcoholics anonymous. Alcoholism Treatment Quarterly 2014; 32(2): $214-224$.

http://dx.doi.org/10.1080/07347324.2014.907032

9. Kelly JF. How do people recover from alcohol dependence? A systematic review of the research on mechanisms of behavior change in Alcoholics Anonymous. Addiction Research and Theory 2009; 17(3): 236-259.

http://dx.doi.org/10.1080/16066350902770458

10. Kolbergytė A. Indrašienè V. Grupinès terapijos elementų taikymo asmenybės saviugdos procese teorinès prielaidos. Socialinis darbas, 2011; 10 (1): 49 - 55.

11. Galanter M. Understanding Alcoholics Anonymous as a spiritual fellowship: from individual to social structure. Alcoholism Treatment Quarterly 2014; 32: 111 - 119.

http://dx.doi.org/10.1080/07347324.2014.907057

12. Petrulyte A., Pileckaitè - Markovienè M., Lazdauskas T. Lètinèmis ligomis sergančių ir sveikų suaugusiujjų sveikatos kontrolès lokuso ir vidinès darnos ypatumai. Psichologija, 2007; 35: 32-41.

13. Pleskevičienè L. Gydytojų psichikos sveikatos, vidinès darnos ir nuostatos savižudybių atžvilgiu ypatumai. Kaunas. Magistro tezès, 2008; 18-19.

14. Tioneng N. Linas - pagalba vaikams. Parankinè knyga vaikų grupių vadovams. Vilnius, 2007; 17-28.

15. Preisaite I. Nuo alkoholio priklausomų asmenų sveikatos kontrolès lokuso sąsajos su vertybinemis orientacijomis ir subjektyviu sveikatos vertinimu. Kaunas. Magistro tezès, 2011; 10.

16. Markevičius G. Blaiviai gyvenančių priklausomų nuo alkoholio asmenų gyvenimo ịprasminimas. Psichologija, 2001; 32: 88 101.

17. Dirsienė J., Zajančkauskaitė-Staskevičienè L. Priklausomų nuo alkoholio asmenų ligos suvokimo ir sveikatos kontrolès lokuso ypatumai. Psichologija, 2010; 41: 84 - 95.

\section{PSYCHO-EMOTIONAL HEALTH OF ALCOHOL ADDICTED PERSONS}

\section{J. Sąlyga, V. Paškevičienė, G. Žiliukas}

Key words: alcohol addiction, psycho-emotional health.

Summary

Alcohol addiction is a severe chronic disease. It disrupts the social environment and psycho-emotional health of both the patients and the people around them. The number of patients increases every year. In 2013 the number of patients receiving treatment for mental and behavioural disorders caused by alcohol consumption in 
Lithuania was 47900 and in $2014-498000$. This thesis discusses the psycho-emotional health of alcohol addicts attending or not attending (receiving stationary treatment) Alcoholics Anonymous (AA) groups.

Research purpose - to analyse the psycho-emotional health of persons addicted to alcohol.

Research methods. Quantitative study. Research instruments: Hospital Anxiety and Depression Scale (HAD) and A. Antonovsky's shortened Orientation to Life Questionnaire (SOC - 13), used to determine the level of internal harmony. The research sample consisted of 322 respondents (170 - attending AA groups and 152 - receiving stationary treatment). The descriptive analysis of the data was done using SPSS 17.0.1 for Windows. The research was conducted in accordance with ethical principles.

Research results. The respondents attending AA groups showed fewer cases of anxiety and depression than those not attending AA groups. The respondents with stronger internal harmony showed lower levels of anxiety and depression than those with weaker internal harmony. The research showed, that aside from attending AA groups, other factors increasing levels of anxiety and depression include younger age, shorter alcohol consumption period, problems related to alcohol addiction, lower educational attainment and joblessness. The factors increasing the levels of anxiety among those that do not attend AA groups, include more frequent alcohol consumption and problems related to alcohol addiction, while loneliness increase the level of both - anxiety and depression. According to the research results, the persons with higher educational attainment and lower alcohol consumption levels showed stronger internal harmony, namely, the sense of meaningfulness and control. In both research groups, depending on their attendance to AA groups, the internal harmony of those that attend AA groups was related to age, while those that do not attend AA groups - to their marital status.

Conclusion. The research showed that persons addicted to alcohol and attending AA groups have better psycho-emotional health than those that do not attend AA groups.

Correspondence to: sekretore@jurlig.lt

Gauta 2016-09-26 